\title{
水素添加による希薄エタノール蒸気-空気混合気の着火促進*
}

\author{
古 市 信 治*1, 松 平 基 志*2 \\ 斎 藤 寛 泰*3, 吉 川 典 彦*1

\section{Ignition Enhancement of Lean Ethanol Vaper-Air Mixture by Hydrogen Addition}

\author{
Shinji FURUICHI*4, Motoshi MATSUDAIRA, \\ Hiroyasu SAITOH and Norihiko YOSHIKAWA \\ *4 Department of Micro-Nano Systems Engineering, Nagoya University, \\ Furo-cho, Chikusa-ku, Nagoya-shi, Aichi, 464-8603 Japan
}

\begin{abstract}
The ignition enhancement effects of hydrogen addition to lean ethanol vapor-air mixtures are experimentally investigated. Hydrogen addition decreases the lean limit of equivalence ratio from 0.80 down to 0.36 . The peak overpressure increases and ignition delay time decreases under the conditions of equivalence ratio below 0.80 . Hydrogen addition effect is also confirmed using detailed computations of reaction mechanism. Chain reactions including $\mathrm{H}_{2}$ are primary ignition enhancing mechanism.
\end{abstract}

Key Words: Ignition, Premixed Combustion, Alternative Energy, Chemical Reaction, Hydrogen Addition

\section{1. 緒言}

近年の二酸化炭素排出削減に関連して，カーボンニ ュートラルであるバイオエタノール燃料の有効活用が 注目されている。ここでは, バイオエタノールの定置 型燃焼装置を想定し，できるだけ広い運転範囲を達成 するために，水素添加による希薄条件での着火促進効 果を検討した. エタノールは, 他の炭化水素燃料と比 べて単位質量当たりの発熱量が低く, 着火しにくいと いう特性をもつ。一方，添加する水素は広い可燃範䎴 をもち，最も着火し易い燃料の一つである．雨者とも 次世代燃料として注目されているが，生産コスト，イ ンフラ整備, 食料生産との関連が大きな課題となって おり，現段階では主要なエネルギ源として普及するこ とができるか，疑問視されることもある。しかし，技 術的な視点からこれらの燃料のさまざまな活用方法を あらかじめ検討しておくことは必要である. 水素添加 による着火促進や燃焼促進は，メタン (1) (8)，プロパン

\footnotetext{
* 原稿受付 2008 年 9 月 3 日。

*1 正員, 名古屋大学工学研究科( 464-8603 名古屋市下種区 不老町).

*2 名古屋大学工学研究科.

*3 正員, 芝浦工業大学工学部(牢135-8548 東京都江東区豊洲 $3-7-5)$.

E-mail : shinji@ yoshilab.nuae.nagoya-u.ac.jp
}

(9) 〜(1)，ガソリン (12) (13)等に適用されて，研究されてい る.しかし，エタノールについての報告は過去に見受 けられず，今後の有効活用を考えると重要である.

液体燃料を用いる多くの燃焼器で濆霧状燃料が用 いられるが，噴霧燃焼場では粒径や数密度分布などの 噴霧特性が現象支支配する要因となり，水素添加のみ の効果を定量評価することが難しくなる．そこで本研 究では，水素添加による着火促進効果の基礎的知見を 得るために，エタノール蒸気を主燃料として扱い，エ タノール蒸気一空気の希薄混合気に水素を添加した際 の定容燃焼挙動を観察すると共に数值解析を行い，水 素を添加したことによる着火促進效果のメカニズムに ついて化学反応の面からも考察を行った。

\section{2. 実験装置およひ実験方法}

本研究で用いた実駼装置を図 1 亿示す，実験に用い た着火試験容器はステンレス製であり， $50 \times 50 \times 100$ $\mathrm{mm}$ の直方体である. 容器の四方の側面には金属製の 蓋が取り付けられている，必要に応じて，蒀を可視化 用の石英ガラスに取り替えることができ, 容器内部の 観測も可能である，容器内壁には，スパークプラグ (DENSO, IW16，ギャップ: $1.1 \mathrm{~mm}$ ，中心電極の径 : $0.4 \mathrm{~mm}$ ), 圧力変換器 (共和電業, PEF-S-10MPSA1, 固有振動数 $37 \mathrm{kHz}$ ) が取り付けられている. 
本研究では，エ夕ノ一蒸気を作る際，液体エ夕， 一ルに溶解している他の成分気体を除去するために脱 気処理を行った. 蒸発を抑えるため, エタノールを入 れて密閉したフラスコを水水に浸して温度を下げ，真 空ポンプでフラスコ内を真空引きして脱気処理した。 その後, フラスコを室温に戻し, エタノール飽和蒸気 を得た。

混合チャンバ内には，水素および空気を分圧法によ って充填し, 水素(4 vol\%)一空気(96 vol\%)混合気，水素 (3 vol\%)一空気(97 vol\%)の混合気があらが゙め作られて いる. 前者の混合気は水素の希薄可燃限界濃度である 4 vol\%の混合気であるが，この混合気のみで大気圧条 件の着火実験を行ったところ，本研究で用いた実験装 置では全く着火しなかった。

エ夕ノール蒸気，水素一空気混合気は，分圧法によ って容器内に充填させる．まず，容器内と配管を真空 にする，その後，エタノール蒸気を充填し，水素一空 気混合気もしくは空気を大気压になるまで容器内に充
填する.

容器内の圧力は, 圧力変換器によって電気信号に変 換され，この電気信号を直流増幅器（UNIPULSE，AM 32）で増幅された後， $\mathrm{AD}$ 変換器を通じてデータ取得 用のコンピュータおよびオシロスコープでデジタル記 録される.データ取得時間は 3 秒間，サンプリング周 波数は $10 \mathrm{kHz}$ とした. パルスディレイジェネレータ (STANFORD RESERCH SYSTEMS, DG535) を手動で 作動させた TTL 信号により, データ取得用のコンピ ユータとオシロスコープの記録を点火に先だって開始 させた，その後，TTL信号を受け取ったイグナイタが 動作し，スパークプラグからの火花（放電エネルギ： 約 $20 \mathrm{~mJ}$ ）により混合気が着火する. 本研究では, 各 条件につき 5 回実験を行った.

\section{3. 実験結果および考察}

各実験条件にお打る混合気の成分, 低発熱量 $H_{\mathrm{L}}$, 総括当量比 $\phi$, 有効当量比 $\phi_{e}^{(1)}$, 着火の有無を表 1 に示 す．表中に示寸有効当量比とは，水素が優先的に完全

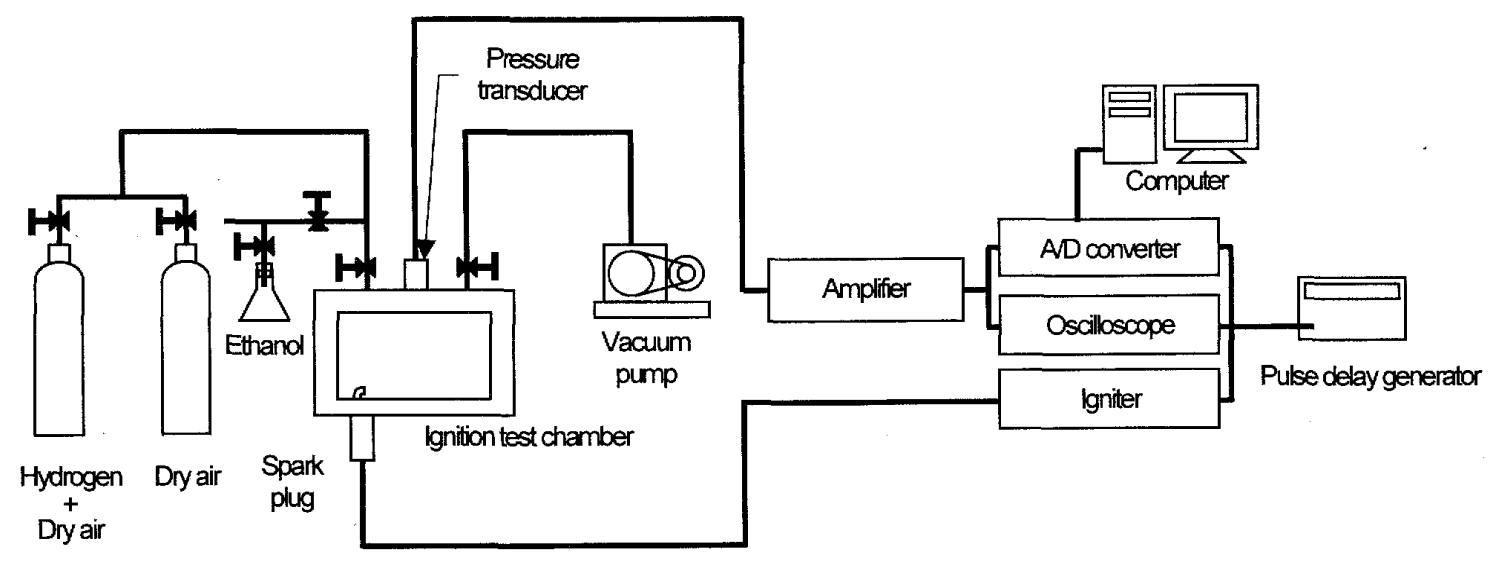

Fig.1 Experimental setup

Table 1 Composition of the premixed gases, lower heating value, equivalence ratio and ignition test results

\begin{tabular}{|c|c|c|c|c|c|c|c|c|}
\hline \multirow{2}{*}{ Gas No. } & \multicolumn{3}{|c|}{ Volume Fraction (vol\%) } & \multicolumn{2}{|c|}{$H_{L}(\mathrm{MJ} / \mathrm{kg})$} & \multirow{2}{*}{$\phi$} & \multirow{2}{*}{$\phi_{\text {effect }}$} & \multirow{2}{*}{ Ignition } \\
\hline & Ethanol Vapor & Hydrogen & Air & Ethanol Vapor & Hydrogen & & & \\
\hline $1-1$ & 1.0 & 0.0 & 99.0 & 0.44 & & 0.153 & $\longrightarrow$ & $x$ \\
\hline $1-2$ & 1.0 & 3.0 & 96.0 & 0.45 & 0.25 & 0.178 & 0.161 & $\underline{x}$ \\
\hline $1-3$ & 1.0 & 4.0 & 95.0 & 0.46 & 0.34 & 0.190 & 0.167 & $x$ \\
\hline $2-1$ & 2.0 & 0.0 & 98.0 & 0.88 & + & 0.308 & & $x$ \\
\hline $2-2$ & 2.0 & 2.9 & 95.1 & 0.90 & 0.25 & 0.338 & 0.324 & $x$ \\
\hline $2-3$ & 2.0 & 3.9 & 94.1 & 0.91 & 0.34 & 0.356 & 0.337 & 0 \\
\hline $3-1$ & 3.0 & 0.0 & 97.0 & 1.31 & 3 & 0.467 & & $x$ \\
\hline $3-2$ & 3.0 & 2.9 & 94.1 & 1.34 & 0.25 & 0.502 & 0.492 & 0 \\
\hline $3-3$ & 3.0 & 3.9 & 93.1 & 1.35 & 0.33 & 0.525 & 0.511 & 0 \\
\hline $4-1$ & 4.0 & 0.0 & 96.0 & 1.73 & & 0.629 & & $x$ \\
\hline $4-2$ & 4.0 & 2.9 & 93.1 & 1.78 & 0.24 & 0.669 & 0.662 & 0 \\
\hline $4-3$ & 4.0 & 3.8 & 92.2 & 1.79 & 0.33 & 0.697 & 0.688 & $O$ \\
\hline $5-1$ & 5.0 & 0.0 & 95.0 & 2.15 & & 0.795 & & 0 \\
\hline $5-2$ & 5.0 & 2.9 & 92.2 & 2.21 & 0.24 & 0.840 & 0.837 & 0 \\
\hline $5-3$ & 5.0 & 3.8 & 91.2 & 2.23 & 0.32 & 0.873 & 0.869 & $\mathrm{O}$ \\
\hline $6-1$ & 6.0 & 0.0 & 94.0 & 2.57 & & 0.964 & $=$ & $\mathrm{O}$ \\
\hline $6-2$ & 6.0 & 2.8 & 91.2 & 2.63 & 0.23 & 1.014 & 1.015 & 0 \\
\hline $6-3$ & 6.0 & 3.8 & 90.2 & 2.66 & 0.31 & 1.053 & 1.054 & 0 \\
\hline
\end{tabular}


燃燒するとして，エタノール蒸気と残りの空気に対し て求めた当量比である. 表中の○は5回中全て着火し た条件を表し，×は5回とも着火しなかった条件を表 す．今回の実験では，着火，不着火は明膫に識別され た. エタノール蒸気と空気の混合気では, $\phi=0.63$ (エ タノール蒸気の体積分率4％）以下の希薄な条件では 着火しないが，エタノール蒸気と空気の混合気に水素 を添加すると， $\phi=0.36$ 以上で着火し，総括当量比の低 い希薄な条件でも安定して着火した，本来は単独では 着火しない水素一空気, エタノール蒸気一空気の2つ の混合気を合体させると，相乗効果によって着火が可 能になることが示された。

次に, 混合気No. 3-1，3-2，3-3の圧力履歴を図2に, 混合気No. 6-1，6-2，6-3の圧履歴を図3に示卞．工夕 ノール蒸気の体積分率が $3 \%$ とき，エタノール蒸気 と空気を混合した条件では圧力上昇が見られず，着火 していない，混合気No. 3-2，3-3では圧力上昇が見られ， 着火していることが確認できた．混合気No. 3-2，3-3の 最大過圧力（過圧力二気体の圧力一初期圧力）を比較

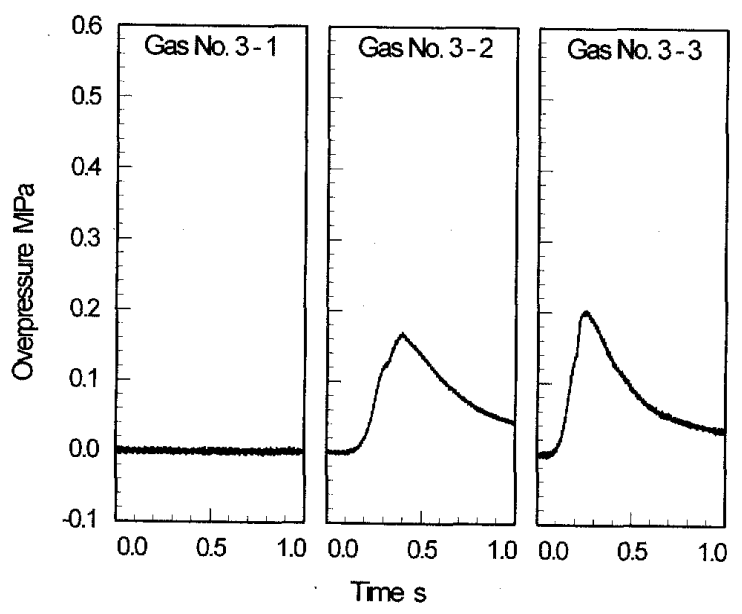

Fig.2 Comparison of overpressure (ethanol 3 vol\%)

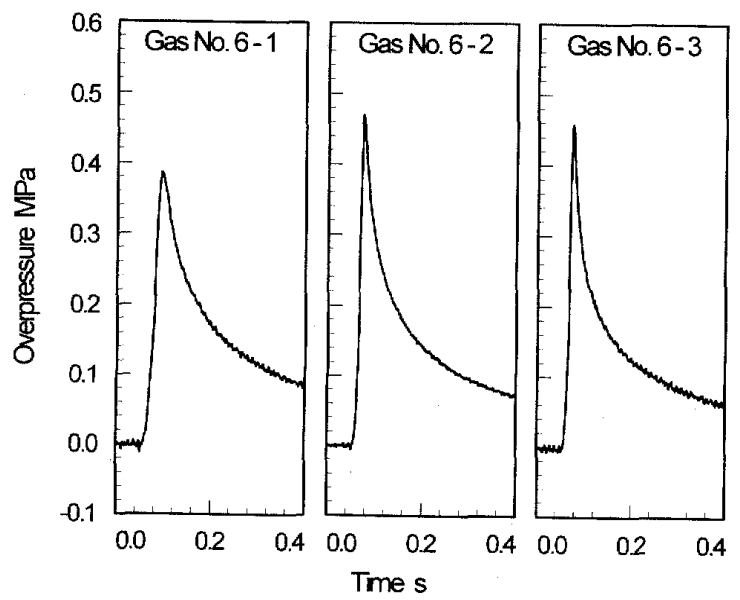

Fig.3 Comparison of overpressure (ethanol 6 vol\%)

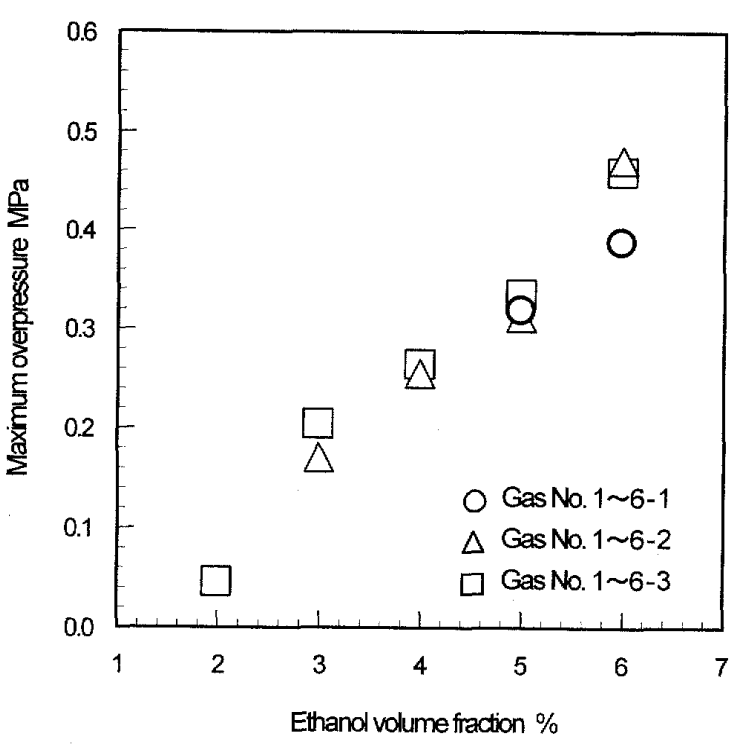

Fig.4 Comparison of peak overpressure

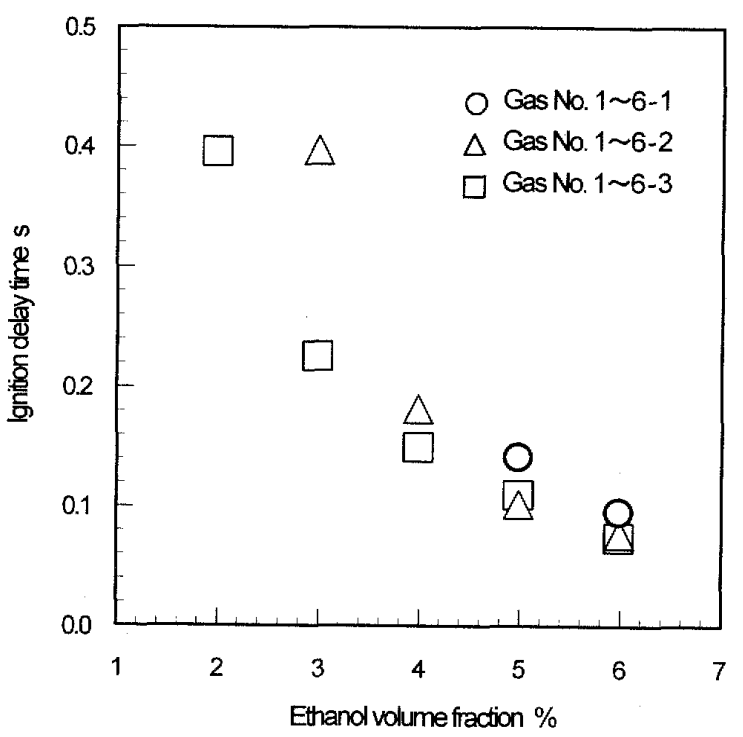

Fig.5 Ignition delay time for peak overpressure

すると，混合気No. 3-3の最大過圧力が大きくなってお り，着火遅れ時間（本論文では，スパークプラグで混 合気を着火させてから最大過圧力に至るまでの時間と 定義する）も短くなっている. エタノール蒸気の体積 分率が6\%のとき，全ての条件で圧力上昇が見られ， 着火している。混合気NNo. 6-1，6-2，6-3の圧力履歴を 比較すると, 混合気NNo. 6-1の最大過圧力が最小上なり, 混合気No. 6-2が最大であった，着火遅れ時閒に関して は, 混合気No. 6-1が最も長くなる。 また, 混合気No. 6-3が最も短い.

次に, 各実験条件における試験容器内の最大過圧力 を比較したものを図4に，着火遅れ時間を比較したも のを図5に示す，水素を添加した効果として，エタ， 
一ル蒝気と混合した水素の体積分率が大きくなるほど 最大過圧力は大きくなっていることが挙げられる．ま た，着火遅れ時間も短くなっていることがわかる。こ れは，水素が添加されることで混合気の着火性がよく なるとともに，燃燒速度が増大したためと考えられる。 エタノール蒸気の体積分率が3％では，全低発熱量中 に水素が担う低発熱量の割合は，No. 3-2，3-3の条件で それぞれ約 $16 \% ， 20 \%$ である. エタノール蒸気が希 薄な条件では, 水素添加の効果は, 圧力履歴, 着火遅 れ時間に影響を及ぼし，水素添加量が多いほど最大過 圧力は高く, 着火遅れ時間は短くなったと考光られる。

一方，エタノール蒸気の体積分率が大きくなるほど 水素を添加した条件としない条件との最大過圧力や着 火遅れ時間の差が小さくなっている. エタノール蒸気 の体積分率が大きくなるにつれ総括当量比と有効当量 比に差が無くなり，水素が当量比全体に占める割合が 小さくなった結果, 水素を添加することによる着火お よび燃焼促進効果が相刘的に低下したためである.ま た，エタノール蒸気の体積分率が5\%，6\%では，全 低発熱量中に水素が担う低発熱量の割合は, 約 $10 \%$ 程度であり, その差が小さいため, 水素添加量の差に よる効果が顕著には現れなくなると考えられる. 水素 が担う低発熱量の割合に差が無くなったため, 水素添 加の効果は圧力履歴, 着火遅れ時間に影響を及ぼして いないと考えられる.

\section{4. 水素添加定容燃焼の数值解析}

\section{1 数值解析方法および初期条件}

数值解析にはCHEMKIN ${ }^{(14)}$ を用いた。化学反忘モデ ルには，383組の素反応と57種類の化学種を含んだ Marinovのエタノールー空気反応モデル ${ }^{(1)}$ を使用する. 定容断熱然焼解析を行い，エタノールー空気混合気一 の水素添加ありと水素添加なしの解析結果を比較する ことにより着火促進メカニズムの評価を行った，初期 条件として混合気の組成 (モル分率) は, 水素添加あ りでは $\mathrm{C}_{2} \mathrm{H}_{5} \mathrm{OH}(3.0 \%)-\mathrm{H}_{2}(3.9 \%)-\mathrm{O}_{2}(19.5 \%)-\mathrm{N}_{2}$ (73.6\%) 水素添加なしの場合 $\mathrm{C}_{2} \mathrm{H}_{5} \mathrm{OH}(3.0 \%)-\mathrm{O}_{2}(20.4 \%)$ $-\mathrm{N}_{2}(76.6 \%)$ とし, 実験で行った混合気No. 3-3 と混合 気No. 3-1の条件と混合気の組成が一致するようにした. 初期圧力は $0.1 \mathrm{MPa}$ ，初期温度は900 Kとした。初期压 力と初期温度の值は, 最大過圧力と最大過圧力に達す るまでの時間とが実験值にほぼ等しくなるように設定 した．この計算は，実験との定量比較を意図するもの ではなく, モデル計算によって, 着火促進に寄与する 素反忘を明らかにすることを目的とする。

\section{$4 \cdot 2$ 記号}

$H_{j}: j$ 番目の素反応による熱発生速度

$W_{i j}$ : 化学種 $i$ $j$ 番目の素反応による反応速度

$h_{i}:$ 化学種 $i$ のモル当りのエンタルピ

$R$ : 普遍気体定数

$T \quad$ : 温度

$v_{F i j}:$ 化学種 $i$ の $j$ 番目の素反応における前進反応 の化学量論係数

$v_{B i j}$ : 化学種 $i$ の $j$ 番目の素反応における後退反応 の化学量論係数

$X_{F i j}$ : 化学種 $i$ の $j$ 番目の素反心における前進反応 のモル反応速度

$X_{B i j}$ : 化学種 $i$ の $j$ 番目の素反応における後退反応 のモル反応速度

\section{$4 \cdot 3$ 水素添加による反応メカニズムの変化}

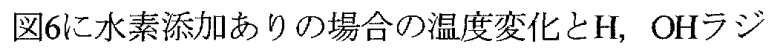
カルのモル分率変化，図7に水素添加なしの場合を同 様に示す，水素添加ありと水素添加なし共に急激な温 度上昇が見られる，H， OHラジカルのモル分率は共 に上昇し着火に至っているが，水素添加ありでは，着 火に至るまでにHラジカルのモル分率が水素添加なし に比べ増加している。

次に，どの素反応が温度上昇に寄与しているかを知 るため，各素反応による熱発生速度を求めた。ここで，

$$
\begin{aligned}
& H_{j}=-\sum_{i=1}^{N_{s}}\left(h_{i}-R T\right) W_{i j} \\
& W_{i j}=\left(v_{F i j}-v_{B i j}\right)\left(X_{F j}-X_{B j}\right) \\
& \mathrm{OH}+\mathrm{H}_{2} \rightleftharpoons \mathrm{H}+\mathrm{H}_{2} \mathrm{O} \\
& \mathrm{O}+\mathrm{H}_{2} \rightleftharpoons \mathrm{OH}+\mathrm{H} \\
& \mathrm{H}+\mathrm{O}_{2} \rightleftharpoons \mathrm{O}+\mathrm{OH}
\end{aligned}
$$

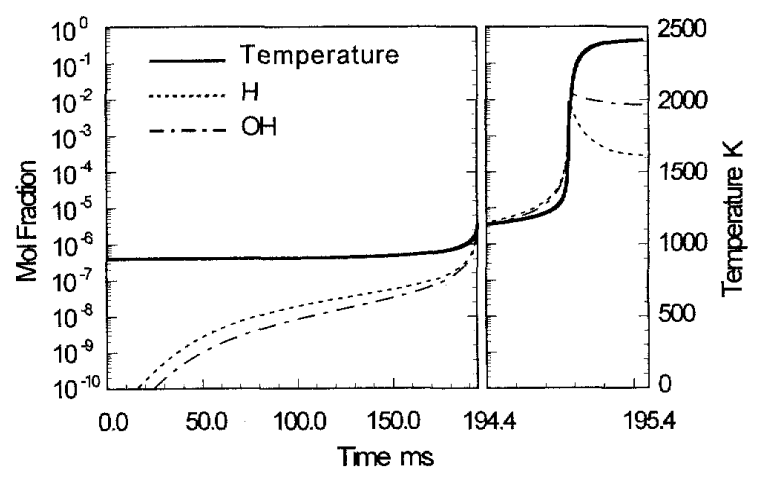

Fig.6 Time history of $\mathrm{H}, \mathrm{OH}$ mole fraction and temperature (Ethanol $3.0 \mathrm{vol} \%+$ Hydrogen $3.9 \mathrm{vol} \%+$ Air $93.1 \mathrm{vol} \%$ ) 


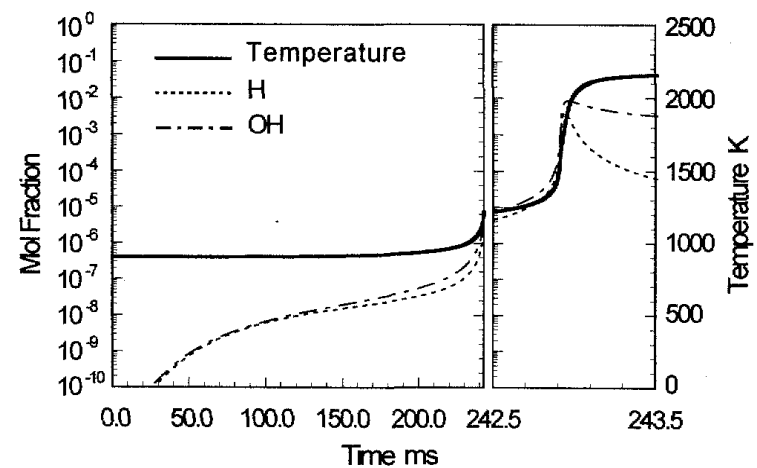

Fig.7 Time history of $\mathrm{H}, \mathrm{OH}$ mole fraction and temperature (Ethanol $3.0 \mathrm{vol} \%+$ Air $97.0 \mathrm{vol} \%$ )

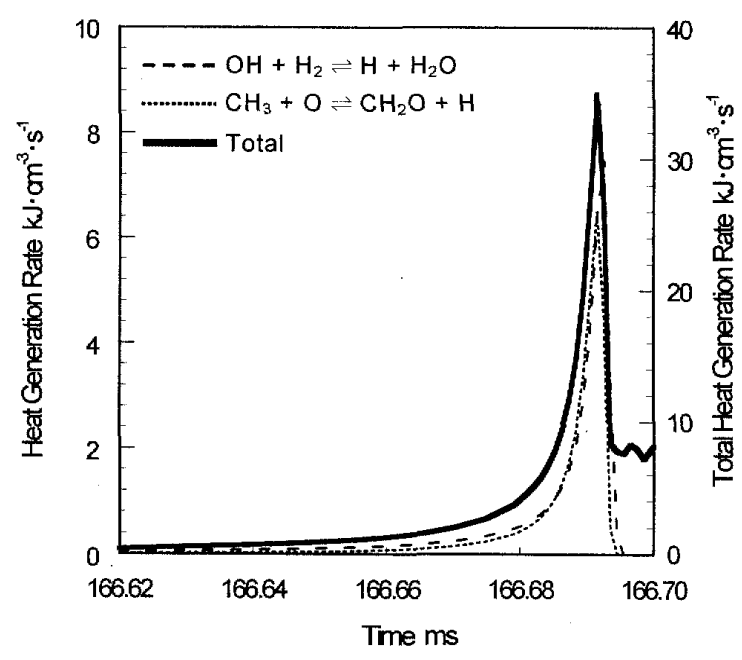

Fig.8 Time history of heat generation rate

(Ethanol $3.0 \mathrm{vol} \%+$ Hydrogen $3.9 \mathrm{vol} \%+$ Air $93.1 \mathrm{vol} \%$ )

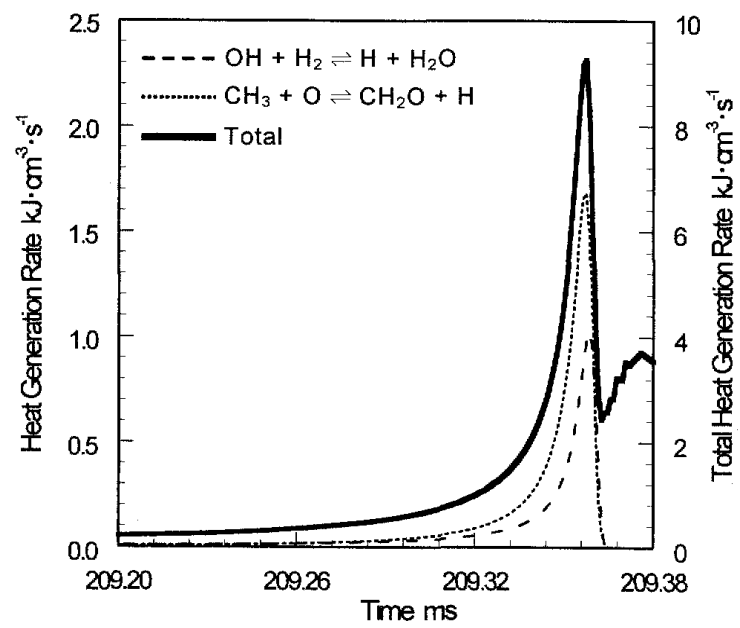

Fig.9 Time history of heat generation rate (Ethanol 3.0 vol\% + Air 97.0 vol\%)

熱発生速度とは各素反応において順方向・逆方向の反 応を考慮した単位時間当りの正味の発熱量（=発熱量

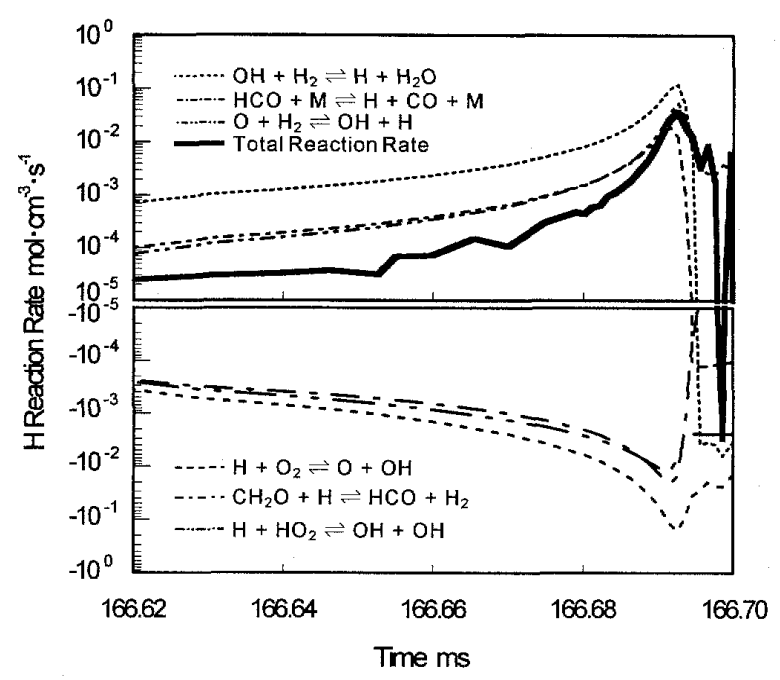

Fig.10 Time history of Reaction Rate of $\mathrm{H}$

(Ethanol $3.0 \mathrm{vol} \%+$ Hydrogen $3.9 \mathrm{vol} \%+$ Air $93.1 \mathrm{vol} \%$ )

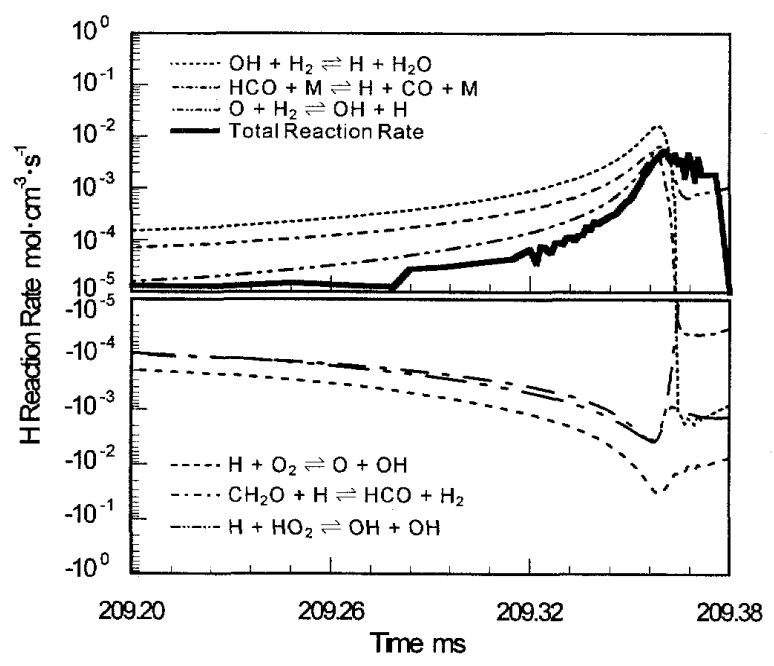

Fig.11 Time history of Reaction Rate of H (Ethanol $3.0 \mathrm{vol} \%+$ Air $97.0 \mathrm{vol} \%$ )

一吸熱量）を表す．熱発生速度の定義式を式(1)に示 す. 図8に水素添加ありの場合の主な素反応の熱発生 速度の時間変化，図9に水素添加なしの場合の主な素 反応の熱発生速度の時間変化を示す，図中に示す素反 応式は，発熱に対して寄与が上位のものを示している。 図8中に示寸式(3)の前進反応は，水素分子を消費する 発熱反応であり，水素を添加した効果により式(3)の 前進反応の熱発生速度が上昇している。

発熱反応に必要な $\mathrm{H}, \mathrm{OH}$ ラジカルを生成・消費す る反応過程を知るために $\mathrm{H}, \mathrm{OH}$ ラジカルの反応全体 での反応速度および各素反応での反応速度を求めた。

ここで，反応速度とは各素反応において順方向，逆方 向の反応を考慮した単位時間当りの正味の反心量（= 


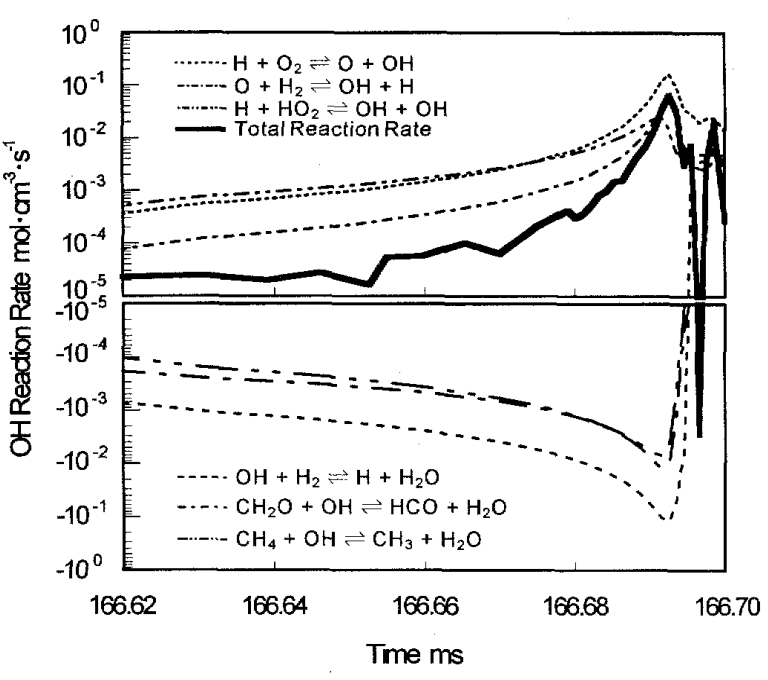

Fig.12 Time history of Reaction Rate of $\mathrm{OH}$

(Ethanol $3.0 \mathrm{vol} \%+$ Hydrogen $3.9 \mathrm{vol} \%+$ Air $93.1 \mathrm{vol} \%$ )

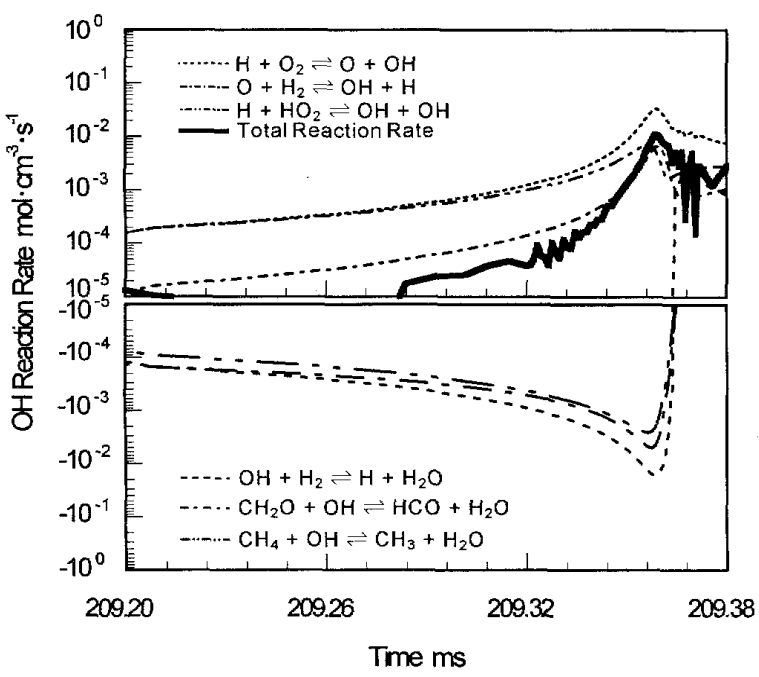

Fig.13 Time history of Reaction Rate of $\mathrm{OH}$ (Ethanol $3.0 \mathrm{vol} \%+$ Air $97.0 \mathrm{vol} \%$ )

生成量一消費量）を表す，反応速度の定義式を式(2) に示す．図 10 に水素添加ありの場合の H ラジカルの 反応速度，図 11 に水素添加なしの場合の H ラジカル の反応速度, 図 12 に水素添加ありの場合の $\mathrm{OH}$ ラジ カルの反応速度, 図 13 に水素添加なしの場合の $\mathrm{OH}$ ラジカルの反応速度を示す．図 10 中にも示した式(3) の前進反応，式(4)の前進反応は，共に水素を消費し $\mathrm{H}$ ラジカルを生成する逐次反応，連鎖分岐反応であり， 式(5)の前進反応は，H ラジカルを消費する連鎖分岐反 応である. 水素を添加したことにより $\mathrm{H}$ ラジカルの 生成，消費速度の上昇している．図 12 中の式(4)の前 進反応は，水素を消費し $\mathrm{OH}$ ラジカルを生成する連鎖

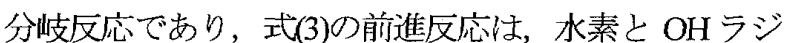
カルを消費する逐次反応である. 水素を添加したこと により $\mathrm{OH}$ ラジカルの生成，消費速度が上昇している また， H， OH ラジカルの感度解析から，水素添加に よって式(3)と(4)の感度が，他の反忘に比心゙著しく上 昇することがわかった， H， OH ラジカルを含む各素 反応がお互いにラジカルを生成・消費し合い，着火に 到ると考えられる．特に $\mathrm{H}$ ラジカルの生成は，着火 の促進に大きく影響を及ぼしていることがわかる。

\section{5. 結言}

希薄エタノール蒸気一空気混合気, 希薄エタノール 蒸気一水素一空気混合気の着火寒験を行い，さらに定 容燃焼過程の数值解析によって水素添加による着火促 進メカニズムの評価を行い，以下の知見を得た．

(1) 希薄可燃限界以下の水素の添加でもエタノールの 体積分率 $4 \%$ 以下のエタノール希薄な状態で着火の促 進に効果がある。しかしながら，体積分率 $5 \%$ 以上で は水素添加の効果はあまり見られない．

(2) 本実験装置では，水素一空気混合気だけでは着火 していない．また，エタノール蒸気一空気混合気では $\phi=0.795$ 以上でなければ着火していない，しかしなが ら，エ夕ノール蒸気一空気混合気に水素を添加するこ とにより, $\phi=0.356 （ \phi=0.337 ）$ まで着火可能になり, エタノール蒸気の可燃範团を拡大寸ることができてい る.

(3) 水素を添加することによりエタノール蒝気が希薄 な状態で最大過圧力は増加し, 最大過圧力までの到達 時間を短縮させられる.エタノ一ル蒸気が過濃である とき，着火を促進する効果が現れなくなった。

(4) 定容断熱然焼解析の結果から，水素を添加するこ とにより，素反応式中に水素分子を含䖝反応への寄与 が高くなる．特に，水素分子と O ラジカルとの反応， 水素分子と $\mathrm{OH}$ ラジカルとの反応への寄与が高くなる.

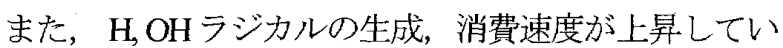
る. 活性ラジカルが生成，消費され，水素分子を優先 的に消費し，その結果，着火が促進された。

\section{謝辞}

本研究の遂行にあたり，文部科学省科学研究費（研 究代表者 : 斎藤寛泰, 若手研究(B), H17, 課題番号 17760163）の支援を受けた。ここに謝意を表す. 
文 献

(1) Yamamoto, K. et al., Effects of Hydrogen Addition on Lean Combustion, Transactions of the Japan Society of Mechanical Engineers, Series B, vol.64, No.622,(1998-6), pp.1919-1924.

(2) Guo, H. et al., "The effect of hydrogen addition on flammability limit and $\mathrm{NO}_{\mathrm{x}}$ emission in ultra-lean counterflow $\mathrm{CH}_{4}$ air premixed flames", Proceedings of the Combustion Institute, vol.30, (2005), pp.303-311.

(3) Nakahara, M. et al., An Experimental Study on Local Flame Displacement Velocity of Hydrogen Added Methane Premix Turbulent Flames, Transactions of the Japan Society of Mechanical Engineers, Series B, vol.73, No.736, (200712), pp.2579-2586.

(4) Strakey, P. et al., Investigation of the effects of hydrogen addition on lean extinction in a swirl stabilized combustor, Proceedings of the Combustion Institute, vol.31, (2007), pp.3173-3180.

(5) Tseng, C-J., Effect of hydrogen addition on methane combustion in a prous medium bumer, Hydrogen Energy, vol.27, (2002), pp.699-707.

(6) Porpatham, E. et al., Effects of hydrogen addition on the performance of a biogas fuelled spark ignition engine, Hydrogen Energy, vol.32,(2007),pp.2057-2065.

(7) Halter, F. et al., Characterization of the effects of hydrogen addition in premixed methane/air flames, Hydrogen Energy, vol.32, (2007), pp.2585-2592.

(8) Tanoue, K. et al., Study on Combustion Improvement of Lean Methane Mixtures by Hydrogen Addition, Proceedings of the
Combustion Institute, vol.66, No.641， (2000-1) , pp.280285 .

(9) Kawanobe, Y. et al., Effect of Hydrogen Addition to Hydrocarbon Fuels on Combustion Characteristic, Transactions of the Japan Society of Mechanical Engineers, Series B, vol.71, No.704, (2005-4), pp.11771182.

(10) Kido, H. et al., Turbulent Buming Velocities of TwoComponent Fuel Mixtures of Methane, Propane and Hydrogen, Transactions of the Japan Society of Mechanical Engineers, Series B, vol.66, No.651, (2000-11), pp.30213026.

(11) Sakai, Y. et al., An Improvement of Lean Combustion Characteristic of Heavy-Hydrocarbon Fuels with Hydrogen Addition, Transactions of the Japan Society of Mechanical Engineers, Series B, vol.65, No.637,(1999-9), pp.3191-3195.

(12) D'Andrea, T. et al., The addition of hydrogen to a gasolinefuelled SI engine, Hydrogen Energy, vol.29, (2004), pp.15411552.

(13) Mandilas, C. et al., Effects of hydrogen addition on laminar and turbulent premixed methane and iso-octane-air flames, Proceedings of the Combustion Institute, vol.31, (2007), pp.1443-1450.

(14) Kee, R. J., et al., Rep. SAND89-8009 (1989).

(15) Marinov, N. M., A Detailed Chemical Kinetic Model for High Temperature Ethanol Oxidation, Int. J. Chem. Kinet, vol.31, (1999), pp.183-220. 